\title{
Effect of Vaginal pH on Efficacy of the Dinoprostone Gel on Labor Induction and Outcomes
}

\author{
Aruna Kumari ${ }^{1}$, Suman L Sharma ${ }^{2}$, Anita Pal ${ }^{3}$, Vikas Bhatia ${ }^{4}$
}

\begin{abstract}
Aim: To study the effect of vaginal pH on the efficacy of the dinoprostone gel for cervical ripening/labor induction and the effect on fetal and maternal outcomes.

Methods: A prospective study over one year was conducted and all term pregnancies with induced labor and who satisfied the inclusion criteria were screened for enrollment. Total of 500 subjects was enrolled in this study. These subjects were divided into two groups, group I ( $\mathrm{pH}<5.5$ ) had 199 subjects, group II $(\mathrm{pH} \geq 5.5)$ had 301 subjects.

Results: Overall delivery outcome was better in group II ( $\mathrm{pH} \geq 5.5)$ as compared to group I ( $\mathrm{pH}<5.5)$. Mean bishop score changes (over 12 hours) were also better in group II. Similarly, the need for the second dose, mean duration from induction to active labor and delivery was less, more subjects delivered vaginally, in group II $(\mathrm{pH} \geq 5.5)$ as compared to group I.

Conclusion: Vaginal pH appears to be one important factor that influences the efficacy of PGE2 gel, results being better with high $\mathrm{pH}$ ( $\mathrm{pH} \geq 5.5$ ). Keywords: Dinoprostone, Induction of labor, Pregnancy, Vaginal pH.

Journal of Postgraduate Medicine, Education and Research (2019): 10.5005/jp-journals-10028-1316
\end{abstract}

\section{INTRODUCTION}

Induction of labor is used to initiate cervical ripening and promote uterine contractions. About $20-30 \%$ of all pregnancies require labor induction. ${ }^{1-3}$ Various prostaglandins have been used as inducing agents in different doses and routes. PGE2 results in softening of the cervix by inducing changes in extracellular ground substance, promoting enzymatic activity, e.g., collagenase and elastase and also an alteration in glycosaminoglycan and hyaluronic acid levels. ${ }^{4,5}$ Multiple commercial formulations for clinical use are available. Effective clinical outcome with prostaglandin usage is multifactorial and not clearly understood. Vaginal $\mathrm{pH}$ has been shown to be a significant factor affecting the prostaglandin effect. ${ }^{6-8}$ The aim of the present study was to analyze the effect of vaginal $\mathrm{pH}$ on the efficacy of dinoprostone gel for labor induction and its effect on maternal and fetal outcomes.

\section{Methods}

This prospective study was conducted for one year and included all term pregnancies with labor induction. Inclusion criteria were singleton pregnancy with vertex presentation, no contraindication to vaginal delivery, unfavorable cervix with bishop score of $<6$, lack of spontaneous uterine contractions and reactive nonstress test (NST). Exclusion criteria were a premature rupture of membranes, chorioamnionitis, and previous cesarean section.

A detailed history of eligible subjects was taken including the history of any medication or pessary use or prior pelvic examination. Informed consent was taken. Subjects were admitted to the labor ward 12 hours before scheduled induction. Cardiotocography (CTG) was performed to rule out fetal distress and monitor uterine contractions. A sample of cervicovaginal fluid was collected from the external cervical OS, cervix, and upper vagina with a cotton swab. Vaginal $\mathrm{pH}$ was then assessed with both broad- and narrowrange $\mathrm{pH}$ paper (universal $\mathrm{pH}$ (1-14) LABSTAR). After $\mathrm{pH}$ and initial cervical assessment, an initial Bishop score was assessed. According to $\mathrm{pH}$ subjects were divided into group I $(\mathrm{pH}<5.5)$ and II $(\mathrm{pH} \geq 5.5)$. All women received a pre-induction intracervical dose
${ }^{1}$ Senior Resident, ${ }^{2}$ Resident, ${ }^{3}$ Professor, ${ }^{4}$ Assistant Professor

${ }^{1}$ Department of Obstetrics and Gynaecology, Postgraduate Institute of Medical Education and Research, Chandigarh, India

2,3 Department of Obstetrics and Gynaecology, Indira Gandhi Medical College, Shimla, Himachal Pradesh, India

${ }^{4}$ Department of Radiodiagnosis, Postgraduate Institute of Medical Education and Research, Chandigarh, India

Corresponding Author: Vikas Bhatia, Assistant Professor, Department of Radiodiagnosis, Postgraduate Institute of Medical Education and Research, Chandigarh, India, e-mail: drvikasbhatia@gmail.com

How to cite this article: Kumari A, Sharma SL, Pal A, Bhatia V. Effect of Vaginal pH on Efficacy of the Dinoprostone Gel on Labor Induction and Outcomes. J Postgrad Med Edu Res 2019;53(2):72-74.

Source of support: Nil

Conflict of interest: None

of the dinoprostone gel $(0.5 \mathrm{mg})$. Both patients and physicians were blinded to initial $\mathrm{pH}$ and bishop score measurement. After the initial 12 hours of cervical ripening, repeat bishop score was assessed. Subjects with improved bishop score $(>6)$, regular uterine contractions, or in active labor ( $4 \mathrm{~cm}$ dilatation with regular uterine contractions) were not given another dose of PGE2 gel. Subjects who did not meet the above-mentioned criteria even after the initial 24 hours of cervical ripening received the second dose. Subjects who did not show any improvement in initial bishop score even with two doses of PGE2 gel were taken up for cesarean section for failed induction. Final outcomes in terms of a number of doses received, subjects going into active labor, time from induction to active labor and delivery, and neonatal outcomes (Apgar score) were noted.

\section{Statistical Analysis}

To analyze the delivery outcome comparison of maternal and prenatal factors were made between groups I and II. The continuous and categorical variables were reported as mean \pm SD and percentage respectively. Significance of difference in the distribution between two groups was analyzed using an unpaired

(c) The Author(s). 20190pen Access This article is distributed under the terms of the Creative Commons Attribution 4.0 International License (https://creativecommons. org/licenses/by-nc/4.0/), which permits unrestricted use, distribution, and non-commercial reproduction in any medium, provided you give appropriate credit to the original author(s) and the source, provide a link to the Creative Commons license, and indicate if changes were made. The Creative Commons Public Domain Dedication waiver (http://creativecommons.org/publicdomain/zero/1.0/) applies to the data made available in this article, unless otherwise stated. 
Student t-test for continuous variables and $\mathrm{X} 2$ test for categorical variables. Statistical analysis was done using statistical software Epi Info version 7 . A $p$ value $<0.05$ was considered significant.

\section{Results}

The study included 500 patients, out of these 199(39.8\%) subjects having low $\mathrm{pH}(<5.5)$ were enrolled in group I while remaining 301 $(60.2 \%)$ with high $\mathrm{pH}(\geq 5.5)$ were enrolled in group II. Mean age for groups I and II were $26.73 \pm 3.39$ and $27.84 \pm 4.08$ years, respectively. Group I had a higher proportion of primigravida 111 (55.7\%) subjects compared to group II 95 (31.56\%). Most primigravida (58.5\%) of group I had initial Bishop score 2 while in group II most (42.11\%) primigravida had initial bishop score 4 and similarly Bishop scores of multigravida in group II were significantly more than those in group I (Table 1). The most common indication for induction in both groups was postdated pregnancy (Table 2). Repeat bishop score after 12 hours was noted in both groups (Table 3 ). Most of the subjects in group II delivered within 12 hours of cervical ripening while most of the subjects in group I had no change in bishop score after initial 12 hours of cervical ripening irrespective of gravidity and this difference was statistically significant. The number of primigravida subjects requiring repeat dose was more in group I when compared with group II while in multigravida this difference was not significant. It was observed that most of the subjects in group II delivered within 6 hours of intracervical instillation while those in group I took 18-24 hours for delivery. A higher number of group II subjects had vaginal delivery as compared to group I after a single dose of PGE2 gel instillation while there was no significant statistical difference in the mode of delivery between two groups after two doses of PGE2 gel instillation. There was no statistically significant difference in maternal complications between the two groups (Table 4). Apgar scores at five minutes in group I and group II showed that there was no statistically significant difference (Table 5). More number of subjects had a vaginal delivery in group II as compared to group I who had prior pelvic examination and received antibiotics or pessary and, there was lesser need of the second dose, more number of vaginal deliveries and reduced mean time to delivery in group II as compared to group 1 (Table 6).

\section{Discussion}

In the present study, the mean age was 26.73 and 27.84 years for groups I and II, respectively which was comparable to that observed by Ramsey et al., ${ }^{9}$ Singh et al. ${ }^{10}$ In present study, in group I, number of primigravida subjects were $55.7 \%$ which is comparable to that observed by Ramsey et al. ${ }^{9}$ (62.5\%) and lower than that observed by Singh et al. ${ }^{10}$ (75\%). A number of multigravida subjects in the present study were $44.22 \%$ which is comparable to that observed by Ramsey et al. (37.5\%) and higher than Singh et al. (25\%). Primigravida enrolled in group II (31.56\%) was lower than that observed by

Table 1: Initial Bishop score

\begin{tabular}{|c|c|c|c|c|}
\hline \multirow[b]{2}{*}{$\begin{array}{l}\text { Bishop } \\
\text { score }\end{array}$} & \multicolumn{2}{|c|}{ Primigravida $(n=206)$} & \multicolumn{2}{|c|}{ Multigravida $(n=294)$} \\
\hline & $\begin{array}{l}\text { Group I } \\
(n=111) \\
(p H<5.5)\end{array}$ & $\begin{array}{l}\text { Groupll } \\
(n=95) \\
(p H \geq 5.5)\end{array}$ & $\begin{array}{l}\text { Group I } \\
(n=88) \\
(p H<5.5)\end{array}$ & $\begin{array}{l}\text { Group II } \\
(n=206) \\
(p H \geq 5.5)\end{array}$ \\
\hline 2 & $65(58.56 \%)$ & $15(15.78 \%)$ & $28(31.81 \%)$ & $17(8.25 \%)$ \\
\hline 3 & $23(20.72 \%)$ & $21(22.11 \%)$ & $40(45.45 \%)$ & $39(18.93 \%)$ \\
\hline 4 & 11 (9.91\%) & 40 (42.11\%) & 14 (15.91\%) & 65 (31.55\%) \\
\hline 5 & $12(10.81 \%)$ & $19(20 \%)$ & $6(6.82 \%)$ & $85(41.26 \%)$ \\
\hline
\end{tabular}

Ramsey et al. ${ }^{9}(55.6 \%)$ and Singh et al..$^{10}$ (84\%) whereas a number of multigravidae $(68.43 \%$ ) was higher than that observed by Ramsey et al..$^{9}(44.4 \%)$ and Singh et al. ${ }^{10}(16 \%)$. These differences can be attributed to large sample size in the present study (n 500) as compared to studies conducted by Ramsey et al. (n 63) and Singh et al. (n 45).In the present study, in group I, mean gestational age was $39.52 \pm 1.63$ SD weeks which is comparable to that observed by Ramsey et al. ${ }^{9}$ (39.8 $\pm 1.1 \mathrm{SD}$ weeks) and lower than that observed by Onen et al. ${ }^{11}$ ( $41.67 \pm 1.3 \mathrm{SD}$ weeks). In group II mean gestational age was $39.39 \pm 0.98$ SD weeks which was comparable to that observed by Ramsey et al. ${ }^{9}$ (39.1 \pm 1.3 SD weeks) but lower than that observed by Onen et al. ${ }^{11}$ (41.68 \pm 1.7 SD weeks).

In the present study, the most common indication for induction was postdated pregnancy (54\%) which was comparable to that observed by Raza et al. ${ }^{12}$ (50\%). In our study, group I patients had shown a change in bishop score of $2.8 \pm 0.96 \rightarrow 7.3 \pm 4.8$ after 12 hours, this difference was higher than observed by Ramsey et al. ${ }^{9}(2.8 \pm 1.0 \rightarrow 3.2 \pm 2.5)$ and Singh et al..$^{10}(3.4 \pm 1.27 \rightarrow 3.72 \pm 1.5)$. In group II change in bishop score after 12 hours was $3.93 \pm 0.98 \rightarrow$ $10.25 \pm 4.27$ which was higher than observed by Singh et al. ${ }^{10}$ $(3.3 \pm 1.03 \rightarrow 5.57 \pm 2.11)$ and Ramsey et al. ${ }^{9}(2.9 \pm 1.5 \rightarrow 3.3 \pm 2.4)$. In the study conducted by Ramsey et al., ${ }^{9}$ initial bishop score was lower with more primigravida subjects while in the present study there was high initial bishop score and a higher proportion of multigravida subjects in patients with $\mathrm{pH} \geq 5.5$ which might be the cause for improvement in bishop score.

In the present study; single dose was instilled in $68.34 \%$ and $86.04 \%$ subjects which is lower than that observed by Onen et al. ${ }^{11}$ i.e., $81.6 \%$ and $18.4 \%$ in group I and group II, respectively, need of the second dose was observed in $31.65 \%$ and $13.9 \%$ subjects which is higher than that observed by Onen et al. ${ }^{11} 92 \%$ and $8 \%$ in group I and II respectively. Time taken from intracervical instillation to delivery/cesarean section was $14.28 \pm 6.31$ SD and $9.88 \pm 5.65$ SD hours, which was lower than that observed by Ramsey et al. ${ }^{9}$ (33.7 \pm 17.2 and $31.4 \pm 13.9)$ and Onen et al. ${ }^{11}(20.0 \pm 21.4$ and $17.6 \pm 12.0)$

Table 2: Indications for induction of labour

\begin{tabular}{|c|c|c|c|c|c|}
\hline \multicolumn{2}{|l|}{ Indications } & \multicolumn{2}{|c|}{$\begin{array}{c}\text { Primigravida } \\
(\mathrm{n}=206)\end{array}$} & \multicolumn{2}{|c|}{$\begin{array}{l}\text { Multigravida } \\
\quad(\mathrm{n}=294)\end{array}$} \\
\hline & & $\begin{array}{l}\text { Group I } \\
(\mathrm{n}=111) \\
(\mathrm{pH}<5.5)\end{array}$ & $\begin{array}{l}\text { Group II } \\
(\mathrm{n}=95) \\
(\mathrm{pH} \geq \\
5.5)\end{array}$ & $\begin{array}{l}\text { Group I } \\
(\mathrm{n}=88) \\
(\mathrm{pH}<5.5)\end{array}$ & $\begin{array}{l}\text { Group II } \\
(n=206) \\
(p H \geq 5.5)\end{array}$ \\
\hline Post date & 252 & $\begin{array}{l}45 \\
(40.54 \%)\end{array}$ & $\begin{array}{l}42 \\
(44.21 \%)\end{array}$ & $\begin{array}{l}46 \\
(52.27 \%)\end{array}$ & $\begin{array}{l}119 \\
(57.76 \%)\end{array}$ \\
\hline $\begin{array}{l}\mathrm{PIH} / \text { pre- } \\
\text { eclampsia }\end{array}$ & 174 & $\begin{array}{l}41 \\
(36.94 \%)\end{array}$ & $\begin{array}{l}40 \\
(42.11 \%)\end{array}$ & $\begin{array}{l}26 \\
(29.54 \%)\end{array}$ & $\begin{array}{l}67 \\
(32.52 \%)\end{array}$ \\
\hline IUGR & 17 & 7 (6.31\%) & $\begin{array}{l}5 \\
(5.26 \%)\end{array}$ & 3 (3.41\%) & $\begin{array}{l}2 \\
(0.97 \%)\end{array}$ \\
\hline $\mathrm{BOH}$ & 15 & 0 & 0 & $\begin{array}{l}6 \\
(6.82 \%)\end{array}$ & 9 (4.36\%) \\
\hline ICP & 14 & $\begin{array}{l}6 \\
(5.41 \%)\end{array}$ & $\begin{array}{l}4 \\
(4.21 \%)\end{array}$ & $\begin{array}{l}2 \\
(2.27 \%)\end{array}$ & $\begin{array}{l}2 \\
(0.97 \%)\end{array}$ \\
\hline Poor BPP & 13 & $\begin{array}{l}4 \\
(3.60 \%)\end{array}$ & $\begin{array}{l}2 \\
(2.11 \%)\end{array}$ & $\begin{array}{l}3 \\
(3.41 \%)\end{array}$ & $\begin{array}{l}4 \\
(1.94 \%)\end{array}$ \\
\hline $\begin{array}{l}\text { PIH with } \\
\text { DM }\end{array}$ & 6 & $\begin{array}{l}3 \\
(2.70 \%)\end{array}$ & 0 & $1(1.14 \%)$ & 2 (0.97\%) \\
\hline $\begin{array}{l}\text { Diabetes } \\
\text { mellitus }\end{array}$ & 6 & $\begin{array}{l}3 \\
(2.70 \%)\end{array}$ & 1 (1.05\%) & 1 (1.14\%) & $1(0.48 \%)$ \\
\hline $\begin{array}{l}\text { Rh } \\
\text { pregnancy }\end{array}$ & 3 & $\begin{array}{l}2 \\
(1.80 \%)\end{array}$ & 1 (1.05\%) & 0 & 0 \\
\hline
\end{tabular}


Effect of Vaginal pH on Efficacy of the Dinoprostone Gel on Labor Induction and Outcomes

Table 3: Repeat Bishop score after 12 hours

\begin{tabular}{lllll}
\hline $\begin{array}{l}\text { Outcome } \\
\text { after 12 hours }\end{array}$ & $\begin{array}{l}\text { Primigravida } \\
(\mathrm{n}=206)\end{array}$ & $\begin{array}{l}\text { Multigravida } \\
(\mathrm{n}=294)\end{array}$ \\
\hline & $\begin{array}{l}\text { Group I } \\
(\mathrm{n}=111) \\
(\mathrm{pH}<5.5)\end{array}$ & $\begin{array}{l}\text { Group II } \\
(\mathrm{n}=95) \\
(p H \geq 5.5)\end{array}$ & $\begin{array}{l}\text { Group I } \\
(\mathrm{n}=88) \\
(p H<5.5)\end{array}$ & $\begin{array}{l}\text { Group II } \\
(\mathrm{n}=206) \\
(p H \geq 5.5)\end{array}$ \\
\hline $\begin{array}{l}\text { No change in } \\
\text { Bishop score }\end{array}$ & $55(49.54 \%)$ & 30 & 25 & 20 \\
Entered & $20(18.02 \%)$ & $\begin{array}{l}(31.58 \%) \\
\text { active phase }\end{array}$ & $(28.41 \%)$ & $(9.71 \%)$ \\
Delivered & $36(32.43 \%)$ & $\begin{array}{l}55 \\
(57.89 \%)\end{array}$ & $\begin{array}{l}(28.41 \%) \\
(43.18 \%)\end{array}$ & $\begin{array}{l}(17.48 \%) \\
\end{array}$ \\
\end{tabular}

Table 5: Apgar score at five minute

\begin{tabular}{llll}
\hline $\begin{array}{l}\text { Apgar score at } \\
5 \text { min }\end{array}$ & $\begin{array}{l}\text { Group I } \\
(p H<5.5) \\
(n=199)\end{array}$ & $\begin{array}{l}\text { Group II } \\
(p H \geq 5.5)\end{array}$ & \\
$(n=301)$ & $p$ value \\
\hline$>7$ & $166(83.42 \%)$ & $265(88.04 \%)$ & 0.147 \\
$<7$ & $33(16.58 \%)$ & $36(11.96 \%)$ & \\
\hline
\end{tabular}

in groups I and II, respectively. This difference is observed because in present study time was taken from intracervical instillation to delivery irrespective of dose whereas studies conducted by Ramsey et al. ${ }^{9}$ and Onen et al. ${ }^{11}$ time was taken from the first dose.

In the present study, group I, $67.83 \%$ of subjects had vaginal delivery which is higher than that observed by Onen et al. ${ }^{11}$ $(60.5 \%)$ and Singh et al. ${ }^{10}(35 \%)$, lower rates of cesarean section (32.16\%) than that observed by Onen et al. ${ }^{11}$ (39.5\%) and Singh et al. ${ }^{10}(65 \%)$, in group II, $87.7 \%$ subjects had higher rates of vaginal delivery than observed by Onen et al. (76\%) and Singh et al. (68\%) and rates of cesarean section(12.29\%) was less as compared to these studies. In the present study; neonates of $26.58 \%$ and $11.96 \%$ subjects had Apgar score of $<7$ at five minute which is higher than that observed by Onen et al ( $2.6 \%$ and $16 \%)$ in groups I and II, respectively which can be attributed to more number of subjects requiring second dose instillation hence more complications like hyperstimulation in the present study as compared to that observed by Onen et al. ${ }^{11}$

Induction of labor is one of the most common interventions being done by obstetricians with an increased risk of cesarean delivery and its associated complications. In the present study, when vaginal $\mathrm{pH}$ was compared with the efficacy of PGE2 gel it was observed that the overall delivery outcome was better in group II $(\mathrm{pH} \geq 5.5)$ as compared to group I $(\mathrm{pH}<5.5)$ like better mean bishop score changes (over 12 hours), less number of subjects receiving second dose, less mean time from induction to delivery, more number of subjects delivered vaginally in group II.

Our study showed that vaginal pH appears to be an important factor that can influence the efficacy of PGE2 gel. Better maternal and fetal outcomes were seen with high vaginal $\mathrm{pH}(\mathrm{pH} \geq 5.5)$. However, it has to be noted that apart from vaginal $\mathrm{pH}$ other variables can also positively influence the outcome of induced labor which includes maternal age, gravidity, gestational age, initial bishop score, and prior pelvic examination (sweeping / stretching). Further randomized studies with the incorporation of these variables are required to evaluate the effect of vaginal $\mathrm{pH}$ on maternal and fetal outcomes.
Table 4: Maternal complications

\begin{tabular}{lllll}
\hline & \multicolumn{2}{c}{ Single dose $(\mathrm{n}=395)$} & \multicolumn{2}{c}{ Double dose $(\mathrm{n}=105)$} \\
\cline { 2 - 5 } & $\begin{array}{l}\text { Group I } \\
(\mathrm{pH}<5.5)\end{array}$ & $\begin{array}{l}\text { Group II } \\
(\mathrm{pH} \geq 5.5)\end{array}$ & $\begin{array}{l}\text { Group I } \\
(\mathrm{pH}<5.5)\end{array}$ & $\begin{array}{l}\text { Group II } \\
(\mathrm{pH} \geq 5.5) \\
(\mathrm{n}=42)\end{array}$ \\
Complications & $(\mathrm{n}=136)$ & $(\mathrm{n}=259)$ & $(\mathrm{n}=63)$ & 28 \\
\hline Nil & 116 & 238 & 44 & 28 \\
& $(85.29 \%)$ & $(91.89 \%)$ & $(69.84 \%)$ & $(66.66 \%)$ \\
$\mathrm{PPH}$ & $6(4.41 \%)$ & $11(4.24 \%)$ & - & - \\
Hyper- & $14(10.29 \%)$ & $10(3.86 \%)$ & $8(12.70 \%)$ & $6(14.28 \%)$ \\
stimulation & & & & \\
\hline
\end{tabular}

Table 6: Comparison of overall delivery outcomes

\begin{tabular}{llll}
\hline & $\begin{array}{l}\text { Group I } \\
(p H<5.5) \\
(\mathrm{n}=199)\end{array}$ & $\begin{array}{l}\text { Group II } \\
(\mathrm{pH} \geq 5.5)\end{array}$ & \\
$(\mathrm{n}=301)$ & $p$ value \\
\hline Need of 2nd dose & $63(31.65 \%)$ & $37(12.29 \%)$ & 0.000000191 \\
Failed induction & $11(5.53 \%)$ & $4(2.01 \%)$ & 0.56 \\
Vaginal delivery & $135(67.84 \%)$ & $264(87.7 \%)$ & 0.000000107 \\
$\begin{array}{l}\text { Time to delivery } \\
\text { (in hours) }\end{array}$ & $14.28 \pm 6.309$ & $9.88 \pm 5.657$ & 0.00 \\
PPH & $17(8.54 \%)$ & $19(6.31 \%)$ & 0.379 \\
$\begin{array}{l}\text { Neonatal } \\
\text { admission in NICU }\end{array}$ & $39(19.59 \%)$ & $49(16.27 \%)$ & 0.252 \\
\hline
\end{tabular}

\section{References}

1. Hayashi RH. Spontaneous and induced cervical ripening: natural dilation and effacement process and current cervical ripening techniques. J Reprod Med 1993;38:66-72.

2. Trofatter KF. Cervical ripening. Clin Obstet Gynecol 1992;35:476-486.

3. Keirse MJNC. Prostaglandins in preinduction cervical ripening: metaanalysis of worldwide clinical experience. J Reprod Med 1993;38:89-100

4. Theobald PW, Rath W, Kuhnle H, Kuhn W. Histological and electronmicroscopic examinations of collagenous connective tissue of the non-pregnant cervix, the pregnant cervix, and the pregnant prostaglandin-treated cervix. Arch Gynecol 1982;231:241-245.

5. Uldbjerg N, Ekman G, Malmström A, et al. Biochemical changes in human cervical connective tissue after local application of prostaglandin E2. Gynecol Obstet Invest 1983;15:291-299.

6. Johnson TA, Greer IA, Kelly RW, et al. The effect of $\mathrm{pH}$ on release of PGE2 from vaginal and endocervical preparations for induction of labour: an in-vitro study. Br J Obstet Gynaecol 1992;99:877-880.

7. MacDonald IA, Weir RF. The effect of $\mathrm{pH}$ on release of PGE2 from vaginal and endocervical preparations for induction of labour. Br J Obstet Gynaecol 1993;100:1066-1067.

8. Lyrenas S, Clason I, Ulmsten U. In vivo controlled release of PGE2 from a vaginal insert $(0.8 \mathrm{~mm}, 10 \mathrm{mg})$ during induction oflabour. $\mathrm{Br}$ J Obstet Gynaecol 2001;108:169-178.

9. Ramsey PS, Ogburn PL Jr, Harris DY, et al. Effect of vaginal pH on efficacy of controlled release dinoprost gel on labour induction/ cervical ripening. J MaternFetal Neonatal Med. 2003 Apr;13(4): 250-253.

10. Singh U, Malhrotra S, Gupta HP, et al. A prospective double blind trial investigating impact of vaginal $\mathrm{pH}$ on efficacy of dinoprost gel for cervical ripening and course of labour. J Obstet Gynaecol 2011;31 (3):217-219.

11. Onen S, Ozaksit G, Yilmaz B, et al. The role of vaginal pH on efficacy of controlled release dinoprostone vaginal insert for cervical ripening/ labour induction: A prospective double blind study. Journal of the Turkish German Gynecological Association 2008;9:206-211.

12. Raza F, Majeed S. Intracervical PGE2 GEL for Cervical Ripening and Induction of Labour. Pak J Med Sci April 2008;24 (2):241-245. 